\title{
ReCENT DeVELOPMENTS In SEXUAL HARASSMENT LAW: TOWARDS A NEW MODEL
}

\author{
ANITA MACKAY*
}

\begin{abstract}
Despite more than 20 years of sexual harassment being unlawful, it is still a persistent problem in Australian workplaces and one which is grossly under-reported. The law is this area should seek both to redress the harm suffered by the victim and to reduce the power imbalance between males and females. The effectiveness of the Sex Discrimination Act 1984 in achieving these objectives was reviewed by a Senate Committee in 2008. One of its recommendations was for positive duties to be imposed on employers to eliminate sexual harassment. This article outlines how this recommendation might be implemented, and taken further, by shifting the onus away from the victim and onto the more powerful players in any sexual harassment scenario - the harasser, the employer and the community in the relevant workplace.
\end{abstract}

\section{INTRODUCTION}

Sexual harassment comprises a range of intimidating behaviours, which range from verbal teasing to conduct that is criminal, for example, sexual assault. Whilst sexual harassment may occur in many social settings (such as on the street or in the home), the focus of this article is employment, ${ }^{1}$ which is the area in which more than 90 per cent of complaints arise. ${ }^{2}$ Part II of this article provides statistics and describes the nature of sexual harassment in Australia.

\footnotetext{
* BA LLB (Hons) (Macquarie); LLM (ANU).

${ }^{1}$ Although it must be recognised that change in the public sphere cannot be achieved in isolation from addressing inequality in the private sphere - see Beth Gaze, 'Twenty Years of the Sex Discrimination Act: Assessing its Achievements' (2005) 30(1) Alternative Law Journal 3, 3 .

${ }^{2}$ Peter Bailey, The Human Rights Enterprise in Australia and Internationally (2009) 577.
} 
Sexual harassment is specifically proscribed by the Sex Discrimination Act 1984 (Cth). Two important objects of that Act are to 'eliminate ... sexual harassment' in certain areas and 'to promote recognition and acceptance within the community of the principle of the equality of men and women'. The current law is outlined in more detail in Part III of the article.

The effectiveness of the Sex Discrimination Act 1984 was assessed in 2008 by the Senate Standing Committee on Legal and Constitutional Affairs (hereafter 'Senate Committee'). ${ }^{4}$ Although the Act aims to eliminate sexual harassment and promote equality, the current law is constructed according to a complaintbased model that relies on individual victims coming forward and reporting the harassment that they have experienced. The Senate Committee heard evidence of a number of problems with this approach.

The Senate Committee was persuaded that the onus should be shifted somewhat, by imposing positive duties on employers. In its report of 12 December 2008, it made the following recommendation:

The Committee recommends that further consideration be given to amending the Act or the EOWW Act ${ }^{5}$ to provide for positive duties for public sector organisations, employers, educational institutions and other service providers to eliminate sex discrimination and sexual harassment, and promote gender equality. ${ }^{6}$

The background that led the Senate Committee to make this recommendation, and the existence of positive duties in the United Kingdom, are outlined in Part IV of the article.

The imposition of positive duties as a response to the problem of sexual harassment in workplaces involves a fundamental shift away from the complaint-based model adopted by the current law. This article explores how the Senate Committee's recommendation might be implemented in Australia and questions whether positive duties will be effective if they are imposed only on employers. It is argued that it may be more beneficial to take the concept of positive duties further so that they extend to would-be harassers

\footnotetext{
${ }^{3}$ Sex Discrimination Act 1984 (Cth) s 3(c) and 3(d).

${ }^{4}$ Senate Standing Committee on Legal and Constitutional Affairs, Parliament of Australia, Inquiry into the Effectiveness of the Commonwealth Sex Discrimination Act 1984 in Eliminating Discrimination and Promoting Gender Equality $<$ http://www.aph.gov.au/Senate/committee/legcon_ctte/sex_discrim/index.htm> at 1 August 2009.

${ }^{5}$ Equal Opportunity for Women in the Workplace Act 1999 (Cth).

6 Senate Standing Committee on Legal and Constitutional Affairs, above $n$ 4, 164 (recommendation 40).
} 
and to other members of the community, for example, witnesses to harassment. A model based on such duties is explained in Part V of the article.

In Part VI, the article examines a reported sexual harassment decision to test whether a different outcome would have been reached if this 'positive duty' model had been applied. This examination will be followed by further assessment of the model in Part VII.

\section{The Nature of Sexual Harassment in Australia}

Before looking at legal responses to sexual harassment, it is useful to examine the prevalence of sexual harassment in Australian workplaces, the types of harm suffered by victims and the reporting rates.

The then Human Rights and Equal Opportunity Commission (HREOC) ${ }^{7}$ conducted a national telephone survey in 2008, which found that 'around one in three women in Australia aged 18-64 have experienced sexual harassment in their lifetime [and] the majority of sexual harassment continues to be experienced in the workplace'. ${ }^{8}$ The same survey found that 'women are around four times as likely to experience sexual harassment compared to men'?

Further, the survey found the following about the reporting of sexual harassment:

The number of people who have formally reported or made a complaint after experiencing sexual harassment has significantly decreased over the last five years. Only $16 \%$ of those who have been sexually harassed in the last five years in the workplace formally reported or made a complaint, compared to $32 \%$ in $2003 .^{10}$

Sexually harassing behaviour that has led to reported decisions includes:

\footnotetext{
${ }^{7}$ HREOC's name was recently changed to the Australian Human Rights Commission by the Disability Discrimination and Other Human Rights Legislation Amendment Act 2009 (Cth) which received Royal Assent on 8 July 2009. However, for the purposes of this article it will be referred to as HREOC.

${ }^{8}$ Human Rights and Equal Opportunity Commission (HREOC), Sexual Harassment: Serious Business (2008)('Serious Business') 1.

${ }^{9}$ Ibid 12.

${ }^{10}$ Ibid 2. The complaints in question here include complaints within workplaces and to external agencies such as the state and territory equal opportunity commissions and the Australian Human Rights Commission: at 2 fn 4.
} 
- sending emails containing sexually suggestive cartoons and jokes: Kaldawi v Smiley; ${ }^{11}$

- grabbing breasts and making inappropriate comments about breasts: Caton v Richmond Club Limited $;{ }^{12}$ and

- requesting sexual intercourse for the provision of divorce papers which were needed by the complainant: McAlister $v$ SEQ Aboriginal Corporation \& Lamb. ${ }^{13}$

The harm suffered by victims will obviously vary according to the type of harassment. At the more severe end of the spectrum, where a victim was raped and locked in a tunnel, she suffered an adjustment disorder and agoraphobia, requiring psychiatric and other counselling. ${ }^{14}$ In another case a detective constable who was sexually harassed by her manager for a lengthy period of time became depressed, suffered from serious mood swings and had inflammatory wheezing. ${ }^{15}$

Given the very low percentage of people who report sexual harassment to agencies such as HREOC, and the fact that only a small proportion of these cases proceed to a formal judgment, ${ }^{16}$ the case law may be described as the 'tip of the iceberg'. However, people's perceptions of how well their complaint will be dealt with can be one important factor in their decision whether to report the harassment or not. Twenty-one per cent of people surveyed by HREOC said that they did not report the sexual harassment experienced due to 'lack of faith in the complaint process' ${ }^{17}$ Therefore the way the law is framed and the complaint handling process play an important role in dealing with sexual harassment.

\footnotetext{
${ }^{11}$ Kaldawi v Smiley [2002] VCAT 1754.

${ }^{12}$ Caton v Richmond Club Limited [2003] NSWADT 202.

${ }^{13}$ McAlister v SEZ Aboriginal Corporation \& Lamb [2002] FMCA 109.

${ }^{14}$ Barker v Hobart City Council- unreported jury verdict 1993. See Roland Browne, 'Common Law Victory' (1993) 18(5) Alternative Law Journal 243, 243.

${ }^{15}$ Stubbs v Chief Constable Lincolnshire Police 30 July 1999, ET Case No 38395 of 1996.

${ }^{16}$ The HREOC 2008 telephone survey found that 3 per cent of reported complaints were finalised by a court: Serious Business, above n 8, 32. Thornton's research found that the less than 2 per cent of complaints are heard by a court: Margaret Thornton, 'Sex Discrimination, Courts and Corporate Power' ('Courts and Corporate Power') (2008) 36 Federal Law Review 31,34 .

${ }^{17}$ HREOC, Serious Business, above n 8, 2.
} 


\section{CuRRent LaW (CommonweALTH)}

When the Commonwealth first passed the Sex Discrimination Act 1984, it contained a specific provision on sexual harassment, which was amended in 1992. ${ }^{18}$ Subsection 28A(1) of the Commonwealth Act currently defines sexual harassment as follows:

a person sexually harasses another person (the person harassed) if:

(a) the person makes an unwelcome sexual advance, or an unwelcome request for sexual favours, to the person harassed; or

(b) engages in other unwelcome conduct of a sexual nature in relation to the person harassed;

in circumstances in which a reasonable person, having regard to all the circumstances, would have anticipated that the person harassed would be offended, humiliated or intimidated.

There are three key elements of this definition: First, that the conduct is 'unwelcome'; second that the conduct is of a 'sexual nature'; and, third, that the 'reasonable person' would have anticipated the reaction of the victim, that is, that the victim would feel 'offended, humiliated or intimidated'. These elements will be considered in turn, followed by a discussion of when vicarious liability can be imposed on employers.

\section{A Unwelcome Conduct}

The first key element of this definition is that the conduct is 'unwelcome'. In Aldridge $v$ Booth it was held that the advance, request or conduct was unwelcome if it was 'not solicited or invited by the employee, and the employee regarded the conduct as undesirable or offensive' ${ }^{19}$ HREOC notes that this is a subjective criterion, that is, it will be viewed from the perspective of the complainant. ${ }^{20}$

\footnotetext{
${ }^{18}$ For a discussion of the historical development of Commonwealth legislation governing sexual harassment see Gail Mason and Anna Chapman, 'Defining Sexual Harassment: A History of the Commonwealth Legislation and its Critiques' (2003) 31 Federal Law Review 195.

${ }^{19}$ Aldridge v Booth (1988) 80 ALR 1, 5.

${ }^{20}$ Human Rights and Equal Opportunity Commission (HREOC), Effectively Preventing and Responding to Sexual Harassment: A Code of Practice for Employers (2008)('Code of Practice') 6.
} 


\title{
B Conduct of a 'Sexual Nature'
}

HREOC notes that ' $[\mathrm{t}] \mathrm{he}$ sexual element of sexual harassment is rarely contentious: in most complaints received by the Commission the alleged harassment is clearly of a sexual nature'. ${ }^{21}$ Courts and tribunals will look at the context in which the conduct occurred. For example, in one case flicking rubber bands at a woman's legs was found to be conduct of a sexual nature because it consisted of part of an overall pattern of sexual behaviour. ${ }^{22}$

\section{Reasonable Person Would Have Anticipated the Reaction of the Victim}

The final key element of the definition is the response of the hypothetical 'reasonable person'. The law adopts a case-by-case approach to this requirement. For example, in finding that putting an arm around a co-worker could be sexual harassment, Member Tahmindjis of the Queensland AntiDiscrimination Tribunal stated:

\begin{abstract}
Whether an action is compassionate or reprehensible will depend on the overall context in every case. The context here is that the action was not one between friends of long standing: it was an action by a middle-aged male employer to a young female who had only worked in the office for two weeks. $^{23}$
\end{abstract}

The Senate Committee heard evidence that this element of the definition is particularly problematic. This is discussed in Part IV of this article.

\section{Vicarious Liability}

Section 106 of the Sex Discrimination Act 1984 (Cth) imposes vicarious liability on employers for unlawful acts done by employees in connection with their employment. Liability will not be imposed if 'all reasonable steps' were taken to prevent the behaviour. ${ }^{24}$ The steps taken by an employer will be considered by courts and tribunals on a case-by-case basis and what is reasonable in the circumstances can vary according to factors such as the size of the business. Generally speaking, decision-makers have required employers

\footnotetext{
${ }^{21}$ Ibid 7.

${ }^{22}$ Shiels v James and Lipman Pty Ltd [2000] FMCA 2; referred to in HREOC, Code of Practice, above n 20, 7.

${ }^{23}$ Smith v Hehir and Financial Advisors Aust Pty Ltd [2001] QADT 11; cited by HREOC, Code of Practice, above n 20, 9.

${ }^{24}$ Sex Discrimination Act 1984 (Cth) s 106(2).
} 
to show that they have a sexual harassment policy in place (drafted according to HREOC's Sexual Harassment Code) that has been implemented, for example, through training, education, and translation into other languages if necessary. ${ }^{25}$

Easteal and Saunders' recent study of the outcomes of cases involving claims of vicarious liability found that liability is quite often imposed on employers. The statistics were as follows:

[O]f the 26 Commonwealth cases which included vicarious liability, the complaint against the employer was upheld in 16. In seven of the 10 in which the employer was not found liable, it was held that sexual harassment had not taken place. In only two of the 26 vicarious liability cases were there findings that there was no liability by an employer. ${ }^{26}$

\section{SENATE CommitTEe INQUiRY INTO THE EfFECTIVENESS OF THE SEX DiscriminATION ACT}

On 26 June 2008 the Senate Committee was given a reference by the Senate to inquire into and report on the effectiveness of the Commonwealth Sex Discrimination Act 1984 in eliminating discrimination and promoting gender equality. The Senate Committee received 81 submissions and held a number of public hearings in September 2008. The Senate Committee's report was dated 12 December 2008 and made 43 recommendations. There has been no government response to this report to date.

\section{A General Findings and Summary of Recommendations}

The overall finding of the Senate Committee was that:

the Act has had an impact on the most overt forms of sex discrimination but has been less successful in addressing systemic discrimination. 'Systemic discrimination' refers to policies, practices or patterns of behaviour, which are absorbed into the institutions and structure of society, that create or perpetuate disadvantage for a particular group. ${ }^{27}$

\footnotetext{
${ }^{25}$ See Patricia Easteal and Skye Saunders, 'Interpreting Vicarious Liability with a Broad Brush in Sexual Harassment Cases' (2008) 33(2) Alternative Law Journal 75, 78-9.

${ }^{26}$ Ibid 108.

${ }^{27}$ Senate Standing Committee on Legal and Constitutional Affairs, above n 4, 47.
} 
HREOC's submission to the inquiry noted that systemic discrimination includes work practices and systems which condone sexual harassment. ${ }^{28}$

Evidence given to the Senate Committee supports the HREOC survey findings outlined in Part II that sexual harassment continues to be prevalent and is grossly under-reported. For example, a survey conducted by Engineers Australia found that 22 per cent of female engineers had experienced sexual harassment. ${ }^{29}$ A survey conducted by the Shop Assistant's Union found that, of those who had experienced sexual harassment in the workplace, over one third did not report it as they thought management would ignore their complaint. $^{30}$

The high percentage of women who report having experienced sexual harassment and the low reporting rate are indications that, overall, legal and other methods of preventing sexual harassment have been ineffective. That is, the law is failing to achieve the goal of promoting equality between women and men.

The Senate Committee made specific recommendations about how the Act should deal with sexual harassment. Its recommendations covered the areas of: the definition of sexual harassment, ${ }^{31}$ extension of the application of the provisions ${ }^{32}$ the complaints process ${ }^{33}$ the exemptions from the $\mathrm{Act}^{34}$ and the powers of HREOC and the Sex Discrimination Commissioner. ${ }^{35}$

The Senate Committee made six recommendations requiring further consultation by the Attorney-General's Department ${ }^{36}$ and, significantly, the Senate Committee recommended that a 'public inquiry to examine the merits

\footnotetext{
${ }^{28}$ HREOC submission to Senate Standing Committee on Legal and Constitutional Affairs, Parliament of Australia, Inquiry into the Effectiveness of the Commonwealth Sex Discrimination Act 1984 in Eliminating Discrimination and Promoting Gender Equality (2008) ('Submission') 36.

${ }^{29}$ Senate Standing Committee on Legal and Constitutional Affairs, above n 4, 59-60 (citing submission from the Association of Professional Engineers, Scientists and Managers).

${ }^{30}$ Senate Standing Committee on Legal and Constitutional Affairs, above n 4, 60 (citing submission from the Australian Council of Trade Unions).

${ }^{31}$ Recommendations 15 and 16, which are discussed in more detail later in this section of the article. Senate Standing Committee on Legal and Constitutional Affairs, above n 4, 153-4.

32 Recommendation 17 was that students be given protection from harassment and recommendation 18 was that the Act also apply to harassment by 'customers, clients and other persons', ibid 154.

${ }^{33}$ See recommendations $19-24$, ibid 156-7.

${ }^{34}$ See recommendations 25-8, ibid 159.

${ }^{35}$ Recommendations 29-33, ibid 161.

${ }^{36}$ Recommendations 35-42, ibid 162-4.
} 
of replacing the existing federal anti-discrimination acts with a single Equality Act' be conducted by $2011 .{ }^{37}$ Cusack has argued that such a review would be an important step towards a 'new vision' for the Australian government - a vision which would prioritise the elimination of systemic forms of discrimination. $^{38}$

\section{B Recommendations about the Definition of Sexual Harassment}

The Senate Committee received submissions and heard evidence about problems associated with the third element of the definition in particular, that is, the requirement that 'a reasonable person, having regard to all the circumstances, would have anticipated that the person harassed would be offended, humiliated or intimidated'. ${ }^{39}$

Separately from the Senate Committee process, the 'reasonable person' concept has been the subject of much critique, particularly by feminist scholars. ${ }^{40}$ The first basis on which it can be critiqued is that what is considered 'reasonable' is likely to vary significantly from decision-maker to decision-maker. Taking this one step further, feminist scholars have argued that 'reasonableness' is derived from a male perspective, due to the 'gendered origins of the standard' and male power to 'define gender relations'. Assuming that this is true, it would mean that, despite sounding neutral and objective, the 'reasonable person' concept necessarily fails to take into account women's experiences. ${ }^{42}$

The inadequacy of a gender-neutral standard of reasonableness has led some scholars to argue that a 'reasonable woman' standard should be adopted instead ${ }^{43}$ which is an approach that has received some acceptance by the

\footnotetext{
${ }^{37}$ Recommendation 43, ibid 165.

${ }^{38}$ Simone Cusack, 'Discrimination Against Women: Combating its Compound and Systemic Forms' (2009) 34(2) Alternative Law Journal 86, 91.

${ }^{39}$ Sex Discrimination Act 1984 (Cth) s 28A(1).

${ }^{40}$ The concept may be critiqued on other grounds that are beyond the scope of this article, for example, the application of the standard to disabled people and children - see Mayo Moran, Rethinking the Reasonable Person: An Egalitarian Reconstruction of the Objective Standard (2003).

${ }^{41}$ Ibid 276-7.

${ }^{42}$ Mason and Chapman, above n 18, 218.

43 See for example Caroline Forell, 'Reasonable Woman Standard of Care' (1992) 11 University of Tasmania Law Review 1.
} 
lower courts in the United States of America (but has not been accepted by the Supreme Court). ${ }^{44}$

The first US decision to adopt a 'reasonable woman' standard was Ellison $v$ Brady. ${ }^{45}$ Shoenfelt et al consider that the decision relied on social science research about men's and women's different perceptions of sexually harassing behaviour. ${ }^{46}$ The court explained the reasons for using the standard as follows:

We note that the reasonable victim standard we adopt today classifies conduct as unlawful sexual harassment even when harassers do not realize that their conduct creates a hostile working environment. Well-intentioned compliments by co-workers or supervisors can form the basis of a sexual harassment cause of action if a reasonable victim of the same sex as the plaintiff would consider the comments sufficiently severe or pervasive to alter a condition of employment and create an abusive working environment. ${ }^{47}$

Whilst the 'reasonable woman' standard has received some acceptance in the United States of America, it has not been adopted in Australia. The formulation that most closely approximates the 'reasonable woman' standard is section 58 of the Australian Capital Territory's Discrimination Act 1991 which provides that
a person subjects someone else to sexual harassment if the person makes an unwelcome sexual advance, or an unwelcome request for sexual favours, to the other person or engages in other unwelcome conduct of a sexual nature in circumstances in which the other person reasonably feels offended, humiliated or intimidated (emphasis in original).

This formulation refers to circumstances in which the victim herself 'reasonably feels offended, humiliated or intimidated' (as opposed to referring to how the harasser expects the victim to react). ${ }^{48}$

The 'reasonable woman' standard does not overcome the problem of individual decision-makers using their own standards to reach a decision. As Ashraf puts it, '[i]f male judges are now forced to apply a reasonable woman standard, how can we be so sure that they are now applying a reasonable

\footnotetext{
${ }^{44}$ Moran, above n 40, 277-8.

${ }^{45}$ Ellison v Brady, 924 F 2 d $872\left(9^{\text {th }}\right.$ Cir 1991).

${ }^{46}$ See discussion by Elizabeth Shoenfelt, Allison Maue and JoAnn Nelson, 'Reasonable Person Versus Reasonable Woman: Does it Matter?' (2002) 10 American University Journal of Gender, Social Policy and the Law 633, 647-51.

${ }^{47}$ Ellison v Brady $924 \mathrm{~F} 2 \mathrm{~d} 872$ (9 $9^{\text {th }}$ Cir 1991) 880-1.

${ }^{48}$ See also s 87(11) of South Australia's Equal Opportunity Act 1984.
} 
woman's perception rather than a male-biased view of what the reasonable woman's perception is? ${ }^{49}$

The oft-quoted decision of Justice Einfeld in Hall, Oliver and Reid $v$ Sheiban ${ }^{50}$ provides a case on point. Einfeld J found that any 'sensible woman' would not have been offended by the employer's behaviour, which included asking women in an interview if they were sexually active and, once they were employed, lowering the zips on their uniforms and making sexualised comments. ${ }^{51}$ Although overturned on appeal, this decision does show that the views of the decision-maker can easily infiltrate the standard of 'reasonableness'. ${ }^{52}$

The 'reasonable woman' standard has also been critiqued on ideological grounds. For example, Finley argues that it

implies that women's experiences and reactions are something for women only, rather than normal human responses. Since women are a significant proportion of persons, their experiences should count as the experiences of a reasonable person, not merely as the experiences of a reasonable woman. ${ }^{53}$

Last, it has also been critiqued for adopting a unitary notion of 'women's experience'. In reality, women's experiences are multidimensional and it would be difficult for any objective standard (whether the 'reasonable person' or 'reasonable woman' standard) to capture this. ${ }^{54}$

The Senate Committee heard that the requirement that a person be 'offended, humiliated or intimidated' introduces an element of morality into the law. This echoes the concerns of commentators who argue that this element of the definition undermines women's equality. Specifically, it is argued that, when

${ }^{49}$ Saba Ashraf, 'The Reasonableness of the "Reasonable Woman" Standard: An Evaluation of its use in Hostile Environment Sexual Harassment Claims under Title VII of the Civil Rights Act' (1992) 21 Hofstra Law Review 483, 500.

${ }^{50}$ Hall, Oliver and Reid $v$ Sheiban (1988) EOC $992-227$.

${ }^{51}$ See discussion by Regina Graycar and Jenny Morgan, The Hidden Gender of Law $\left(2^{\text {nd }}\right.$ ed, 2002) 392-3.

${ }^{52}$ For more recent Commonwealth examples, see Fiona Pace, 'Concepts of "Reasonableness" in Sexual Harassment Legislation: Did Queensland Get it Right?' (2003) 3 Queensland University of Technology Law and Justice Journal 1, 14-15.

${ }^{53}$ Lucinda Finley, 'A Break in the Silence: Including Women's Issues in a Torts Course' (1989) 1 Yale Journal of Law and Feminism 41, 64.

${ }^{54}$ Ashraf, above n 49, 502. 
establishing whether the victim was treated less favourably than a man, the focus should be on equality, rather than morality. ${ }^{55}$

The Senate Committee's conclusion was that wording based on the Queensland Anti-Discrimination Act 1991 would be preferable. Section 119 of that Act defines sexual harassment as follows:

Sexual harassment happens if a person -

(a) subjects another person to an unsolicited act of physical intimacy; or

(b) makes an unsolicited demand or request (whether directly or by implication) for sexual favours from the other person; or

(c) makes a remark with sexual connotations relating to the other person; or

(d) engages in any other unwelcome conduct of a sexual nature in relation to the other person;

and the person engaging in the conduct described in paragraphs (a), (b), (c) or (d) does so -

(e) with the intention of offending, humiliating or intimidating the other person; or

(f) in circumstances where a reasonable person would have anticipated the possibility that the other person would be offended, humiliated or intimidated by the conduct.

The Senate Committee's recommendation 15 was that the Commonwealth definition 'be amended to provide that sexual harassment occurs if a reasonable person would have anticipated the possibility that the person harassed would be offended, humiliated or intimidated'.

Further, it recommended that 'the circumstances relevant to determining whether a reasonable person would have anticipated the possibility that the other person would be offended, humiliated or intimidated by the conduct' be specified in the Act and include factors such as the 'sex, age and race of the other person'. ${ }^{57}$

\footnotetext{
${ }^{55}$ This debate is summarised by Mason and Chapman, above n 18, 220-1.

${ }^{56}$ Senate Standing Committee on Legal and Constitutional Affairs, above n 4, 153.

57 Senate Standing Committee on Legal and Constitutional Affairs, above n 4, 153-4 (Recommendation 16). The other circumstances listed were 'any impairment that the other
} 
While this does not remove the concept of reasonableness, it does involve a shift in focus away from the victim and on to the harasser's conduct. ${ }^{58}$ This is a shift that may well be successful. Following a detailed comparison of the approach to reasonableness in Queensland and other jurisdictions, Pace concludes that 'Queensland has formulated, applied and continues to apply a definition of sexual harassment that does not seem to attract the problems identified in other jurisdictions, ${ }^{59}$

\section{Recommendation on Positive Duties}

Of key interest for the purposes of this article, is recommendation 40 (quoted in the Introduction to this article), which entails imposing positive duties on employers to eliminate sexual harassment and promote gender equality. ${ }^{60}$ This recommendation falls under the heading 'recommendations requiring further consultation' and the Senate Committee suggested that the Attorney-General's Department conduct this consultation within 12 months. ${ }^{61}$

Some background to this recommendation is found in the submissions to the inquiry. HREOC submitted that the way the vicarious liability provisions in the Sex Discrimination Act 1984 (Cth) are currently framed, if an employer has taken 'all reasonable steps' to prevent harassment, they may avoid liability. However, 'the failure to take such steps is not actionable of itself' ${ }^{62}$ That is, unless sexual harassment occurs and a complaint is brought, there is no examination of whether an employer has taken any steps to prevent sexual harassment from occurring. HREOC submits that it would be more effective if there were a positive obligation on employers and if failure to meet this obligation were actionable without any sexual harassment having taken place. ${ }^{63}$

The Anti-Discrimination Commission of Queensland and the Western Australian Equal Opportunity Commission submitted that they support the introduction of positive duties into Australian law. ${ }^{64}$ The Western Australian

person has; the relationship between the other person and the person engaging in the conduct; and any other circumstance of the other person'.

${ }^{58}$ Pace, above n 52, 16.

${ }^{59}$ Ibid 21.

${ }^{60}$ Senate Standing Committee on Legal and Constitutional Affairs, above n 4, 164.

${ }^{61}$ Ibid 163.

${ }^{62}$ HREOC, Submission, above n 28, 143.

${ }^{63}$ Ibid 144.

${ }^{64}$ Anti-Discrimination Commission Queensland, Submission to the Senate Standing Committee on Legal and Constitutional Affairs, Parliament of Australia, Inquiry into the Effectiveness of the Commonwealth Sex Discrimination Act 1984 in Eliminating Discrimination and 
Commission's submission discusses the positive duties in existence in the United Kingdom in some detail. ${ }^{65}$

\section{Positive Duties in the United Kingdom}

The Senate Committee noted in the summary of their views that 'the positive duties under the Equality Act 2006 (UK) may provide a useful model which could be adopted and applied either to public sector organisations or to both the public and private sector', ${ }^{66}$ without providing any details about the operation of the law in the United Kingdom.

Part 4 of the Equality Act 2006 (UK) inserted section 76A into the Sex Discrimination Act 1975 (UK), which commenced on 7 April 2007. ${ }^{67}$ That section imposes the following statutory duty on public authorities:

A public authority shall in carrying out its functions have due regard to the need -

(a) to eliminate unlawful discrimination and harassment, and

(b) to promote equality of opportunity between men and women.

There are some limitations on the application of the duty. Besides not applying to the private sector, it does not apply to all public authorities either. (The authorities that are exempt are set out in subsection 76A(3) and include, for example, the House of Commons, the House of Lords, the Church of England and the Secret Intelligence Service). Further, the duty does not apply to the exercise of judicial and parliamentary functions. ${ }^{68}$

The duties imposed by the Sex Discrimination Act 1975 (UK) need to be read in conjunction with the Sex Discrimination Act 1975 (Public Authorities) (Statutory Duties) Order 2006 which was made on 7 November 2006. That Order provides that all authorities listed in the schedule to the Order must publish a Gender Equality Scheme by 30 April 2007. Examples of the

Promoting Gender Equality (2008) 10; Western Australian Equal Opportunity Commission Submission to the Senate Standing Committee on Legal and Constitutional Affairs, Parliament of Australia, Inquiry into the Effectiveness of the Commonwealth Sex Discrimination Act 1984 in Eliminating Discrimination and Promoting Gender Equality (2008) 3.

${ }^{65}$ Brief reference to the UK law is made in the submission by the South Australian Equal Opportunity Commission and the Office for Women.

${ }^{66}$ Senate Standing Committee on Legal and Constitutional Affairs, above n 4, 163.

${ }^{67}$ The Equality Act 2006 (Commencement No 1) Order 2006.

${ }^{68}$ See Equality Act 2006 (UK) s 76A(4). 
authorities covered include the British Library and Museum, the Commissioner of Police and the naval, military and air forces.

A Gender Equality Scheme must outline the objectives which the authority has identified as necessary to comply with the duty in section $76 \mathrm{~A} ;{ }^{69}$ it must be reviewed every three years following which a revised scheme must be published $;^{70}$ and there is also an annual reporting requirement, namely that the authority must publish an annual report of its action taken towards achieving the objectives. ${ }^{71}$

A further step towards imposing positive duties on employers was taken in 2008 through the introduction of the Sex Discrimination Act 1975 (Amendment) Regulations 2008. The 2008 regulations amended section 6 of the Sex Discrimination Act 1975 (UK) so that an employer can be held liable where a third party (for example, a customer) subjects a woman to harassment in the course of her employment, if the employer has failed to take reasonably practicable steps to prevent harassment by third parties. ${ }^{72}$ The employer must have known that the employee had been harassed by a third party on at least two other occasions, but not necessarily by the same third party. ${ }^{73}$ This is likely to impose the heaviest burden in industries, such as hospitality and retail, where staff are dealing with a large volume of customers. ${ }^{74}$

Fredman has highlighted some limitations of the UK legislation. It does not extend to private functions of public authorities and, more significantly, it does not apply to private bodies at all. She writes that 'public bodies or private bodies with public functions will be at a competitive disadvantage as against those private employers who need not comply until subject to an individual complaint' ${ }^{75}$

\footnotetext{
${ }^{69}$ Sex Discrimination Act 1975 (Public Authorities) (Statutory Duties) Order 2006 s 2(4).

${ }^{70}$ Sex Discrimination Act 1975 (Public Authorities) (Statutory Duties) Order 2006 s 4.

${ }^{71}$ Sex Discrimination Act 1975 (Public Authorities) (Statutory Duties) Order 2006 s 6.

${ }^{72}$ Sex Discrimination Act 1975 (UK) ss 6(2B) and 6(2D). Note that recommendation 18 made by the Senate Committee aims to deal with the same problem. It reads the committee recommends that the Act be amended to protect workers from sexual harassment by customers, clients and other persons with whom they come into contact in connection with their employment': Senate Standing Committee on Legal and Constitutional Affairs, above $\mathrm{n}$ $4,154$.

${ }^{73}$ Sex Discrimination Act 1975 (UK) ss 6(2C) and 6(2D)

${ }^{74}$ For further discussion of the background to these regulations see Richard Nicolle 'Hands off!' (2008) 158 New Law Journal 725.

${ }^{75}$ Sandra Fredman 'Reforming Equal Pay Laws' (2008) 37 Industrial Law Journal 193, 214.
} 


\section{E Victoria's Review of Equal Opportunity Laws}

The Victorian Department of Justice recently reviewed the Victorian Equal Opportunity Act 1995. This review sought to overcome the limited application of the UK legislation by recommending a positive 'duty to eliminate discrimination as far as possible' that would apply to both the public and private sectors. ${ }^{76}$ The review envisaged that enforcement could occur through the Victorian Equal Opportunity and Human Rights Commission's 'own motion inquiries without the need for an individual complaint', although it is stated that the primary duty of the Commission should be education and assistance such that organisations comply with the duty. ${ }^{77}$

The Victorian government's 2009 statement of intentions announced that the government was working on legislation to respond to the review, which it expects to introduce into Parliament in late 2009 or early $2010 .^{78}$

\section{A NeW MOdEL}

A deficiency in the current Australian law is that it relies on victims making complaints, which large numbers of women are unwilling to do. Therefore shifting the onus away from the victim is a logical response. There is a common element in the development in this direction so far. The UK legislation, and the Australian Senate Committee and Victorian recommendations are all framed so as to impose a positive duty on employers, who are clearly in a position of power vis-à-vis their employees (both victims and harassers).

\section{A Advantages of Positive Duties}

A significant advantage of the imposition of positive duties over the current individual complaint-based system is that it is forward looking. It is about preventing harassment from occurring, instead of taking action after sexual harassment has taken place.

In the context of reforming equal pay laws, Fredman has highlighted two significant advantages or benefits flowing from positive duties. The first is

\footnotetext{
${ }^{76}$ Victorian Department of Justice, An Equality Act for a Fairer Victoria: Equal Opportunity Review Final Report (2008) 40-1.

${ }^{77}$ Ibid 41.

78 The Premier of Victoria, Annual Statement of Government Intentions (2009) $<$ http://www.premier.vic.gov.au/state-of-government-intentions/statement-of-governmentintentions.html> at 29 August 2009.
} 
that they take the 'burden off individual complainants'. ${ }^{79}$ This is relevant in the Australian context, as the statistics show that many victims of harassment do not bring forward a complaint for various reasons.

These might include the fact that there is no Commonwealth legal aid funding to bring a sex discrimination case. ${ }^{80}$ It is left to the complainant to pay legal costs, often when they are unemployed, ${ }^{81}$ or to represent themselves against their employer who is likely to be well resourced and able to employ a team of legal representatives. ${ }^{82}$ If complainants lose their case they must pay their own costs and there is a trend for complainants to be ordered to pay the respondent's costs. ${ }^{83}$ The power imbalance of the parties may mean that it is difficult for complainants to build up the courage to make a complaint.

The second advantage of positive duties highlighted by Fredman is that 'positive duties require action to be taken by all employers, not just those subject to a successful complaint ${ }^{84}$ This would also be beneficial in the Australian context as a recent survey by the Equal Opportunity for Women in the Workplace Agency found that 40 per cent of organisations do not provide any training on sexual harassment. ${ }^{85}$ The current law does nothing to regulate those workplaces, unless a complaint is made. Even if a successful complaint is brought forward, an employer may choose to pay compensation and then do nothing to prevent harassment from occurring in the future.

\footnotetext{
${ }^{79}$ Fredman, above $\mathrm{n} 75,212$.

${ }^{80}$ Gaze, above $\mathrm{n} 1,6$. This was considered by the Senate Committee and recommendation 24 of their report was 'the committee recommends increased funding be provided to the working women's centres, community legal centres, specialist low cost legal services and legal aid to ensure they have the resources to provide advice for sex discrimination and sexual harassment matters': Senate Standing Committee on Legal and Constitutional Affairs, above n 4, 157.

${ }^{81}$ Margaret Thornton, 'Sexual Harassment Losing Sight of Sex Discrimination' (2002) 26 Melbourne University Law Review 422, 440 ('Losing Sight of Sex Discrimination').

${ }^{82}$ Gaze, above n 1, 6. On the subject of corporate litigants see Thornton, 'Courts and Corporate Power', above n 16, 35.

${ }^{83}$ Thornton, 'Courts and Corporate Power', above n 16, 39. This was recognised as a deterrent by the Senate Committee: Senate Standing Committee on Legal and Constitutional Affairs, above $\mathrm{n} 4,156$.

${ }^{84}$ Fredman, above $\mathrm{n} 75,212$.

${ }^{85}$ The precise findings were reported to be that ' $59.1 \%$ of organisations provide sex-based harassment training for employees, and slightly less provided training to managers (55.4\%)': Australian Government Equal Opportunity for Women in the Workplace Agency, Survey into Paid Maternity Leave, Sex-based Harassment Initiatives and the Gender Pay Gap (2009) 10.
} 


\section{B Imposing Duties on Employers}

As outlined in Part IV, in the United Kingdom compliance with positive duties requires employers to have a Gender Equality Scheme in place and to comply with the associated reporting requirements. A mechanism of this kind would be useful in the Australian context, but is insufficient on its own. As the Equal Opportunity for Women in the Workplace Agency has observed, 'the level of complaints and limited training show that policies alone are not sufficient'. ${ }^{86}$ Any duty on employers should require them proactively to ensure appropriate supervision of employees such that harassment is identified early, otherwise liability will be imposed.

There is a parallel here with existing tort law principles. A negligence action arose in Western Australia when a prisoner was assaulted on two occasions by other prison inmates. The 'mere fact' that the assaults occurred was held to be insufficient to establish a breach of duty by the prison authority. However, the court held that the prison authority's duty to take reasonable care for the safety of prisoners required a system of supervision. This was either lacking, or was not properly implemented, which led to the authority's liability. ${ }^{87}$

Imposing duties on all employers raises the question of the scope of the duty. There is merit in the Victorian Department of Justice's review finding that the duty should apply to both the public and private sectors. ${ }^{88}$ As sexual harassment is prevalent in both types of workplace, there should be a duty to eliminate it from both.

Systems of supervision will not involve a radical departure from what many employers are already doing to avoid vicarious liability. As outlined in Part III, currently vicarious liability will not be imposed if 'all reasonable steps' were taken to prevent the behaviour. However, under the current law, this only becomes an issue when a complaint is made and, as mentioned above, there are a substantial number of employers who do not even provide any training to their employees. Therefore, the big difference is that reasonable steps, in accordance with a public statement about the way they intend to comply with the duty, will need to be taken by all employers.

\footnotetext{
${ }^{86}$ Ibid 12.

${ }^{87}$ Nada v Knight [1990] Aust Tort Reports 81-032, 67,922 (Pidgeon J).

${ }^{88}$ Victorian Department of Justice, above n 76, 40.
} 
This is not without its benefit to employers. The Senate Committee heard evidence that it is common for women who complain of sexual harassment to leave the workplace. ${ }^{89}$ If harassment is prevented in all workplaces,

- employers avoid court ordered damages pay-outs (and associated costs of litigation) and the loss of the skills of employees who leave because of harassment; ${ }^{90}$ and

- employees are able to continue their employment in a harassment-free workplace, which should make the workplace more attractive to potential employees.

\section{Limitations of Imposing Duties on Employers}

There is no doubt that positive duties might be seen to impose a heavy burden on employers, especially small businesses. One potential response to this is that there are already costs involved when a discrimination complaint is brought. There are legal expenses, and there is a trend towards increasingly generous damages payouts being awarded by courts and tribunals. ${ }^{91}$ Furthermore, victims often leave the workplace, taking their skills and experience with them. The suggested model front-loads the costs, so that they are targeted at prevention. Many employers are already taking reasonable steps and complying with HREOC's Sexual Harassment Code to prevent vicarious liability being imposed. This would continue under the new model. The main difference for those employers would be the preparation of a Gender Equality Scheme and the associated reporting requirements. In all cases employers would need to have policies and systems of supervision in place. However, the advantages of a harassment-free workplace should outweigh the burden imposed by this scheme.

Small business contexts, where the employer and the harasser are one and the same, are problematic. In a large number of cases reported to the Victorian Commissioner the sexual harassment had taken place in small businesses

\footnotetext{
${ }^{89}$ Senate Standing Committee on Legal and Constitutional Affairs, above n 4, 60.

${ }^{90}$ However, Thornton notes that 'the possibility of litigation is built into the risk management plans of corporations': Thornton, 'Courts and Corporate Power', above n 16, 35.

${ }^{91}$ Joe Catanzariti, 'Sexual harassment claim: significant damages payout plus costs' (2008) 14(5) Employment Law Bulletin 42. Recent examples include Poniatowska v Hickinbotham [2009] FCA 680 (23 June 2009) where the damages award was $\$ 466000$ and Whitlock $v$ Bunnings, DP and DF [2009] QADT 14 (22 May 2009) where the complainant was awarded $\$ 132818.65$.
} 
where the complainant was the only employee who was not a member of the harasser's family. ${ }^{92}$

A New South Wales example is Taylor v Sciberras. ${ }^{93}$ Ms Taylor was sexually harassed by her boss, Mr Sciberras, who was the owner of the fish and chips shop where she was employed. For the majority of the time they were the only people working at the shop (which is when the harassment occurred), except for occasions when Mr Sciberras' wife was assisting with the evening shifts. Thus there were no witnesses to the harassment and no one more senior than her harasser for Ms Taylor to turn to.

Such businesses would be required to comply with positive duties under the suggested model, but their failure to do so would still require the victim to bring forward a complaint.

\section{Role of the Sex Discrimination Commissioner}

A more effective way of addressing the small business scenario just discussed is to take a further step along the continuum and give greater powers to the Sex Discrimination Commissioner.

The Senate Committee recommended a role for the Sex Discrimination Commissioner that would support the positive duties model. Recommendation 37 of its report was:

that further consideration be given to amending the Act to give the Sex Discrimination Commissioner the power to investigate alleged breaches of the Act, without requiring an individual complaint. ${ }^{94}$

The Victorian review also recommended 'own motion inquiries' by the Victorian Commission. ${ }^{95}$

This power would complement the imposition of positive duties because it would remove the burden on victims of sexual harassment which exists under the current law, and it would also operate as a further incentive for employers to comply with their new duties, that is, to avoid investigation that can lead to the imposition of liability.

\footnotetext{
92 Jenny Morgan, 'Sexual Harassment and the Public/Private Dichotomy: Equality, Morality and Manners' in Margaret Thornton (ed), Public and Private. Feminist Legal Debates (1995) 89, 101.

${ }^{93}$ Taylor $v$ Sciberras [2004] NSWADT 104.

${ }^{94}$ Senate Standing Committee on Legal and Constitutional Affairs, above n 4, 163.

${ }^{95}$ Victorian Department of Justice, above n 76, 41.
} 


\section{E Extending Duties to Would-be Harassers and Bystanders}

It is notable that the existing UK duty and the proposed duties recommended by the Senate Committee and Victorian Department of Justice apply only to employers. Fredman has warned against reliance on employers in the context of attempts to achieve pay equity. She writes that there is a 'need to ensure that it does not become a unilateral, top-down exercise, left entirely in the hands of the employer'. ${ }^{96}$ After all, the employer cannot conceivably control every action of every employee. Nor can the Sex Discrimination Commissioner investigate every workplace in Australia.

A move further along a continuum of shifting the onus away from the victim could entail placing some responsibility for preventing harassment on wouldbe harassers, who are arguably best placed to eradicate harassment. Once more, there are parallels with tort law, particularly the duty of care in negligence. This is now firmly statute-based, under the Civil Liability Acts in various jurisdictions. ${ }^{97}$

In some jurisdictions, a tort-based approach is used specifically to respond to harassment. For example, in the United States of America the tort of 'intentional infliction of emotional distress' encompasses harassment. Section 46 of the Second Restatement of Torts (1966) defines the tort of 'intentional infliction of emotional distress' as the imposition of liability for 'intentionally or recklessly' causing 'severe emotional distress' where the conduct is found to have been 'extreme or outrageous'. ${ }^{98}$ This test for harassment would be difficult to satisfy due to the requirements of 'extreme or outrageous conduct' causing 'severe emotional distress'. The commentary on this provision suggests that the legislators intended to draw a line between conduct that is merely unpleasant and that which comprises 'tortious unpleasantness'. ${ }^{99}$

In the early 1990 s a tort-based approach to harassment emerged in the United Kingdom, based on intentional infliction of emotional distress and private

\footnotetext{
${ }^{96}$ Fredman, above n 75, 212.

${ }^{97}$ See Joachim Dietrich, 'Duty of care under the "Civil Liability Acts"' (2005) 13 Torts Law Journal 17.

${ }^{98}$ For a discussion of the historical development of the tort of harassment in the United States of America, see Martin Lishexian Lee, 'The Need for a Tort of Harassment' (2001) 5 Southern Cross University Law Review 189, 192-4. For a discussion of the application of this tort in broader contexts than sexual harassment see Frank Cavico 'The Tort of Intentional Infliction of Emotional Distress in the Private Employment Sector' (2003) 21 Hofstra Labor and Employment Law Journal 109.

99 Richard Townsend-Smith, 'Harassment as a Tort in English and American Law: The Boundaries of Wilkinson v Downton' (1995) 24 Anglo-American Law Review 299, 313.
} 
nuisance. ${ }^{100}$ However, this was short-lived ${ }^{101}$ and harassment law is now firmly statute-based. ${ }^{102}$

There have been suggestions that there should be a tort of harassment in Australia. ${ }^{103}$ It is outside the scope of this article to enter this debate. The parallel with tort law is merely drawn to show that people already have duties to their fellow workers, and imposing a duty not to harass would complement the duties already imposed on employers.

The final category of people in the workplace who might be subject to positive duties is witnesses and bystanders who are aware that harassment is occurring (for example, through having been told by the victim). The HREOC survey found that 'over one in ten Australians have witnessed sexual harassment in the workplace in the last five years' ${ }^{104}$ In some instances, these witnesses may have been able to take action, such as reporting the harassment to management.

The current law governing sexual harassment imposes no requirements on witnesses or bystanders. To use tort law as a comparison once more - there is no duty in torts law to take action to prevent another person from suffering harm, even when that harm is foreseeable. ${ }^{105}$ Tort law does, however, offer protection to so-called 'good Samaritans' who choose to assist someone who is in need. For example, when a person chooses to provide assistance (that is, to be a 'good Samaritan') and something goes wrong, the question of the good Samaritan's liability arises. At common (tort) law, liability has never been imposed in such a situation. Furthermore, recent legislation has provided immunity as an extra measure of protection for the 'good Samaritan' (in all jurisdictions except Tasmania). ${ }^{106}$ In summary, tort law goes to great lengths

${ }^{100}$ Khorasandjian v Bush [1993] 3 All ER 669. For commentary on how these torts were applied see Keith Stanton, 'Harassment: An Emerging Tort?' (1993) Tort Law Review 179. For commentary on the historical development of the tort of harassment in the United Kingdom, see Lee, above n 97, 190-2.

${ }^{101}$ Khorasandjian v Bush [1993] 3 All ER 669 was overruled by the House of Lords in 1997 in Hunter v Canary Wharf [1997] 2 All ER 426.

102 Protection from Harassment Act 1997 (UK).

${ }^{103}$ See for example Shampa Sinha, 'Sexual Harassment and the Common Law' (1993) 18(2) Alternative Law Journal 58, and Lee, above n 98.

${ }^{104}$ HREOC, Serious Business, above n 8, 1.

105 Sutherland Shire Council v Heyman (1985) 157 CLR 424; Hawkins v Clayton (1988) 164 CLR 539; Jaensch v Coffey (1984) 155 CLR 549.

${ }^{106}$ Dietrich, above n 97, 27. See also James Tibballs, 'Legal Liabilities for Assistance and Lack of Assistance Rendered by Good Samaritans, Volunteers and Their Organisations' (2005) 16 Insurance Law Journal 254. 
to protect people who choose to assist, given that they are under no obligation to do so.

Returning to the context of sexual harassment, at present the imposition of positive duties on witnesses and bystanders might well be a step too far. There may be a host of reasons why people would be reluctant to come forward to assist a victim of sexual harassment, including fear of reprisal by the harasser, their personal opinion that the victim should stand up for themselves, or concern about their own employment status (especially if they are employed on a non-ongoing basis).

Community support for the imposition of legal duties on witnesses and bystanders therefore seems unlikely. The mandatory inclusion in an employer's Gender Equality Scheme of provisions for the education of witnesses as to their moral obligation to intervene, to the extent that they are able, to prevent sexual harassment, and to report if the harassment continues, may be an alternative.

A combination of: 1) positive duties imposed on employers and would-be harassers, 2) education of everyone in the workplace, and 3) new powers for the Sex Discrimination Commissioner would amount to a new model of antiharassment regulation. Would such a model make a difference?

\section{Testing the Model}

The case of McKenna $v$ State of Victoria ${ }^{107}$ (hereafter the 'McKenna case') involved a hostile work environment where the complainant, a Victorian police officer, was subjected to a range of harassing conduct by a number of her male colleagues. The case will now be considered in the light of the new model, following a summary of the facts and the decision that was reached by the Victorian Anti-Discrimination Tribunal (the Tribunal).

\section{A Facts and the Tribunal's Findings}

The complainant made a number of discrimination claims against a number of respondents, all of whom were employed by the Victorian Police. The conduct at issue had occurred over a number of years. It is beyond the scope of this article to outline all the claims, so the focus of this discussion will be the sexual harassment and the procedures in place for preventing discrimination in the workplace.

${ }^{107}$ McKenna v State of Victoria [1998] EOC $992-927$ ('McKenna’). 
The Tribunal heard evidence that the Bairnsdale police station was a work environment where sexist remarks about the role of women being 'in the home' and sexist jokes were commonplace. Coarse language and obscenities were held by the Tribunal to have been part of the environment in which the complainant worked. ${ }^{108}$

The incidents of sexual harassment occurred during a week of nightshift work. The complainant asserted that on the first occasion her supervisor grabbed her and pulled her onto his lap, on the second occasion he said 'come on, Narelle, how about a head job' and on the third occasion he tried to push her into a holding cell. Ms McKenna gave evidence that, in this last situation, she was very fearful about what he might have done to her. ${ }^{109}$ On each occasion, she told her work partner that she did not want to be anywhere near her harasser and they stayed out on patrol, away from the station, for the rest of the shift. She also spoke to a sergeant and a colleague about the problems she was experiencing.

The Tribunal was satisfied that:

the supervisor of the complainant ... made it reasonably appear to the complainant ... that her working conditions were contingent upon her acceptance of his sexual advances or toleration of his persistent sexual suggestions or innuendo. ${ }^{110}$

The complainant transferred to a different police station where she was victimised because she had lodged a complaint with the Victorian Equal Opportunity and Human Rights Commission about events which had occurred at Bairnsdale police station. This added to the harm she suffered, leading to a mental breakdown, following which she took an overdose of valium. ${ }^{111}$

The Tribunal's findings about the harm caused to the complainant relate to the combined effect of her various complaints. She was found to have been

exposed to considerable pain and suffering, to debilitating physical symptoms, to mental breakdown, to humiliation, loss of self esteem and of

\footnotetext{
${ }^{108}$ This section of the judgment is not reported by $\mathrm{CCH}$, but may be found in McKenna $v$ State of Victoria [1998] VADT 83 (1 June 1998) under the heading '4.1 Subjection of the complainant by the first respondent to a sexist work environment, hostile to women or unmarried women'.

${ }^{109}$ McKenna $v$ State of Victoria [1998] EOC $\$ 92-927,78171$.

${ }^{110}$ Ibid 174

${ }^{111}$ Ibid $185-9$.
} 
self confidence, and to loss of normal enjoyment of her professional and private life. $^{112}$

The Tribunal awarded her $\$ 125000$ compensation. ${ }^{113}$

Of note for the purposes of this article were the procedures (or the lack of procedures) in place for the observance of equal employment opportunity (EEO) conditions in the Victorian police force. This was relevant to the Tribunal's assessment of the liability of the Victorian police and its finding that vicarious liability should be imposed. The Tribunal heard evidence that there were one-day EEO courses available to all police officers at the time, but only EEO contact officers were required to attend. ${ }^{114}$ None of the respondents in the McKenna case had attended any training. The EEO contact officer at the Bairnsdale station at the time of the events found out about his appointment as contact officer when he saw his name on the notice board and had not attended any training. ${ }^{115}$

The Tribunal heard evidence from the highest officer in the Victorian police force in charge of EEO matters (the manager of the EEO unit) that showed he was not aware of recent ministerial discussions on sexual harassment, nor of the findings of surveys about incidents of sexual harassment in police forces in other jurisdictions. ${ }^{116}$ The Tribunal found that:

the force appears to have done little to instil in its leaders and senior members a sense of commitment to a culture and management standards for the organisation that brought with it an expectation that every member conform to non discriminatory standards in their work, professional behaviour and attitude. ${ }^{117}$

The question is: would the new model outlined in this article have made a difference to the course of events in the McKenna case?

\footnotetext{
${ }^{112}$ Ibid 195.

${ }^{113}$ Ibid 197. This was appealed to the Supreme Court of Victoria, but the challenge failed - see State of Victoria $v$ McKenna [1999] VSC 310 [263].

${ }^{114}$ McKenna $v$ State of Victoria [1998] EOC $\$ 92-927,78182$.

${ }^{115}$ Ibid 182-3.

${ }^{116}$ Ibid 183

${ }^{117}$ Ibid 184.
} 


\section{B Applying the Model}

In the McKenna case, there were three specific instances of sexual harassment which the complainant told other officers about. If a duty were imposed on harassers, and if bystanders (in this case Ms McKenna's work partner and other people she spoke to) were appropriately trained about their option to report harassment, the likelihood that each incident would have been reported to management would have increased.

When management became aware that sexist remarks and harassing behaviour were being directed at Ms McKenna, they would have had a responsibility to caution the harasser against continuing this behaviour. If the behaviour continued, the employer would have needed to consider ways to prevent the harasser's interaction with Ms McKenna, such as making sure they were not rostered on the same shifts. This would be part of management's responsibility to provide a system of supervision in the workplace.

Would any of this have made a difference to Ms McKenna? Perhaps the key difference would be that she would not have felt so isolated. The supporting action of colleagues may have been encouraging to her and may have increased her resolve to persist in drawing management's attention to the harassing behaviour. Furthermore, if management were proactive as required by their duty to supervise, the harassment may have stopped before it had escalated to the stage where Ms McKenna was being pushed into a holding cell.

If the harasser had failed to respond to warnings, the duty of the employer may have justified taking formal disciplinary action against the harasser.

A significant difference to this scenario would be the requirement for the Victorian Police Force to have a Gender Equality Scheme with the associated reporting requirements. Such public reporting requirements would operate as an incentive for senior management to ensure that there was adequate training and awareness of the anti-harassment policies at all levels of the police force. The training in particular would have reduced the chances of victimisation by officers at a different police station.

A major reason why Ms McKenna felt reluctant to make a complaint was the culture in the police force that discouraged the 'dobbing' in of colleagues. ${ }^{118}$ Her concerns were well founded in light of the victimisation and further harm that flowed from her subsequent complaint to an external body. Such a culture

118 This problem has been discussed by Thornton in relation to the McKenna case, and other cases - see Thornton, 'Losing Sight of Sex Discrimination', above n 81, 432. 
should be challenged from the top down. It is submitted that imposing a positive duty on employers to guard against sexual harassment would be a more effective way to facilitate this cultural change than through the current legislative arrangements. At least two reasons can be given. First, imposition of a duty is aimed at prevention of the problem, rather than dealing with complaints after the fact. Second, the onus is on those in power to make sure that harassment is not taking place, or that it is dealt with promptly if it does occur.

The Sex Discrimination Commissioner's suggested new power might also provide a weapon against the culture of sexual harassment, especially if investigations were carried out.

In summary, the model would have led to different outcomes in the McKenna case in the following ways:

- the police force would have had an anti-harassment policy and a degree of public accountability, which would have been major incentives to conduct proper training throughout the organisation. Such training would, in turn, have encouraged witnesses and bystanders to report harassment to management.

- if harassment had occurred it is likely that it would have been reported to management earlier and responded to before it escalated, therefore limiting the harm suffered by the victim; and

- the complainant would have been more likely to receive support throughout the complaint process (both by her colleagues in the station where the harassment took place and by management), rather than being victimised when she moved to a different station.

\section{FURTHER AsSessment OF THE MOdeL}

In addition to the general advantages of imposing positive duties on employers, the application of the model shows that the reporting rates are likely to improve because reporting may be done by witnesses and bystanders (if they so choose), rather than just victims. This is important given that lack of reporting is a major obstacle to the effectiveness of the existing law. ${ }^{119}$ Employers should be alerted to harassment at an early stage, either by the victim or through any witnesses or bystanders. This should prevent the harassment from escalating and allow an early remedy. The Sex

\footnotetext{
${ }^{119}$ See discussion in Parts II and IVA of this article.
} 
Discrimination Commissioner's proposed powers should also lead to early detection of sexual harassment in workplaces.

Increased reporting produces another benefit, which is the generation of a powerful message that sexual harassment is unacceptable. The generation of such a message is also one of the goals of tort law - the goal of defining when community norms are violated, so that it is clear what type of behaviour is wrongful. ${ }^{120}$ When a judge pronounces that there is a legal duty of care that has been breached (in the case of tort law), or that there has been a breach of positive duties to prevent sexual harassment (in the present context), it sends a clear message to the community that standards and expectations have been violated. $^{121}$

Thornton has suggested that, because there are very few appellate decisions in the area of sex discrimination, particularly by the High Court which has decided only three sex discrimination cases in the last 30 years, these appellate decisions 'carry a great deal of weight'. ${ }^{122}$ One of the objects of the Sex Discrimination Act 1984 (Cth) is that both women and men should be treated equally. Decisions by judges have an important role to play in achieving this objective, as they define examples of behaviour that have violated this goal.

It must be recognised, however, that law reform will never be sufficient of itself to change community attitudes and behaviour; nor will any sexual harassment law be enough to address inequality between the sexes. The model does not stop people who are intent on sexually harassing their colleagues, as those people will make sure they act when no one else is around. This certainly happens now and the model does little to shift the onus away from the victim in these circumstances. The main difference might be in the employer's duty to respond if a victim does come to them for assistance.

\footnotetext{
${ }^{120}$ This line of argument is used by Decle about the Stolen Generation - see Peace Decle, 'The Stolen Generation. Can State Governments be Held Responsible for Reparation through the Law of Torts?' (1998) 23 Alternative Law Journal 168; about exposure of prisoners to HIV by Malkin - see Ian Malkin, 'Tort Law's Role in Preventing Prisoners' Exposure to HIV Infection while in Her Majesty's Custody' (1995) 20 Melbourne University Law Review 423; and about harm suffered by children in immigration detention by Mackay - see Anita Mackay, 'Harm Suffered by Children in Immigration Detention: Can Tort Law Provide Redress?' (2006) 14 Tort Law Review 16.

${ }^{121}$ Malkin, above n 120, 436.

122 Thornton, above $\mathrm{n}$ 16, 35. In this article, Thornton provides a detailed discussion of the High Court's consideration of sex discrimination.
} 


\section{CONCLUSION}

Sexual harassment is a persistent problem in Australian workplaces, which has led bodies such as the Senate Committee to consider different possible solutions to it. Imposing positive duties on employers is a way to shift the onus away from the victim and on to those with more power, but the extent to which the law should travel along this continuum is open to debate.

The goals of eliminating sexual harassment and promoting the principle of the equality of women and men are certainly worthwhile. Positive duties, such as the ones placed on employers in the United Kingdom, have distinct advantages over the complaint-based approach that the Australian law currently adopts. No doubt there will be further examination of the advantages and disadvantages of various models as the Senate Committee's recommendations are debated. 